\title{
4.5 Методи аналізу системогенезу та онтогенезу розвитку кіберспорту в Україні
}

Базисом систематизованої сукупності кроків, які потрібно здійснити для розвитку кіберспорту $є$ аналіз розвитку кіберспортивних організацій, орієнтований на виділення:

- системогенезу функціональних систем (а саме загального відбиття стану сукупності уподібнення різновекторних процесів виробничо-господарської діяльності кіберспортивних організацій всередині цільових формальних груп видавця/розробника кіберспортивної гри);

- онтогенезу їх внутрішнього розвитку (через ідентифікацію еволюції спорідненості кіберспортивних організацій за цими процесами 3 моменту їх утворення до зникнення).

Такі потреби обумовлені тим, що саме виробничо-господарські процеси всередині цільових формальних груп видавця/розробника кіберспортивної гри пов’язані між собою та впливають на якість кіберспортивної гри (як продукту) i якості організації подій (що проходять в віртуальному просторі).

Важливим для видавця/розробника такої гри $є$ досягнення максимальної спорідненості таких процесів, оскільки це формує уніфіковане середовище взаємодії кіберспортсменів у грі та рівні умови змагань.

Щодо процесів ідентифікації системогенезу та онтогенезу у науковій літературі майже відсутні методичні підходи, що містять алгоритми дій, які пристосовані під специфіку розвитку спорідненості кіберспортивних організацій [152, с. 16, с. 18$]$. Це пов'язане з відносно недовгою генезою їх розвитку. Крім того, за даними видавців/розробників така спорідненість полягає у координованості дій 3 виробництва, постачання, організації споживання нематеріальних благ, що є кіберспортивною дисципліною (а саме тих, що за цільовими форматами орієнтовані на потреби видавця/розробника конкретної кіберспортивної гри) починаючи від ігрових спільнот, командних складів, команд, клубів, ліг (що поділяють почуття спільності, щодо їх діяльності) гри до 
операторів кіберспортивних подій $[152$, с. 16, с. 18]. Зміст основних процесів виробничо-господарської діяльності кіберспортивні організації $\epsilon$ наступним $[152$, с. 16, c. 18$]$ :

- процеси виробництва це створення специфічних благ, яке забезпечуються технічними можливостями систем, що у загальному сенсі створюють різноманітні програмні коди, які набувають різноманітної форми та можуть узагальнювати: режим роботи 3 комп'ютерною програмою, інтерфейс користувача, насиченість ігрового процесу; пришвидшена робота 3 комп’ютерною грою; перетворення роботи з комп'ютерною грою на конкретні кіберспортивні послуги.

- процеси постачання, які охоплюють закупівлю, генерування потужностей реплікації та масштабування, що призначені для постачання продуктів та послуг різного виду (на вимогу споживачів) за цільовими формальними групами видавця/розробника кіберспортивної гри;

- процесів 3 організації споживання нематеріальних продуктів та потужностей сервісів, необхідне для їх існування та розвитку.

Специфічним є те, що всі процеси виробничо-господарської діяльності кіберспортивних організацій, всередині цільових формальних груп видавця/розробника кіберспортивної гри, мають відбуватися у єдиних умовах, сформованих багатофункціональними кіберспортивними майданчиками (аренами) та їх глобальним мережами, представленими одноформатними спеціалізованими клубами, базами 3 домашніми аренами для локальних кіберспортивних подій, навчально-тренувальними базами для кіберспортсменів.

Враховуючи зміст таких процесів важливим є їх дослідження коштом різних методів цілеспрямованих дій або їх поєднання, що мають не просто представляються у числових величинах та напрямках, інтерпретованих у багатокрокових ітераціях (повтореннях), а ідентифікуватися як множинні математичні моделі, які надають опис рис спорідненості, уподібнення.

Науковцями нарізі пропонуються до використання різні підходи, що присвячені особливостям ідентифікації у математичних моделях окреслених 
процесів, які можуть трансформуватися відповідно до [140]: специфіки функціонування різнотипових організацій (у т.ч. індустрії розваг); індивідуальної тотожності процесів та тих їх рис, які значущі для набуття стану пов'язаності.

Всі математичні моделі, в залежності від систематизованої сукупності кроків, що ними використовуються, мають властивості до унікалізування (із врахуванням особливостей діяльності конкретної організації). Зокрема, кожна модель містить виняткові змінні рішення: які впливають на ці цілі, враховує обмеження, що існують; які впливають на феноменологію, що визначає субпроцеси, що представлені окремими моделями, вихідні величини яких $є$ вхідними для інших (наступних) субпроцесів.

Хоча ці властивості різняться за ступенем набуття унікальних властивостей, підходи застосовувані для ідентифікації системогенезу функціональних систем та онтогенезу їх розвитку для кіберспортивних організацій, що діють у межах цільових формальних груп видавця/розробника кіберспортивної гри.

Серед методичних підходів, що визначаються, як такі, що придатні для такої ідентифікації, науковцями пропонуються ті, що передбачають створення математичних моделей стану процесів виробничо-господарської діяльності організацій та їх еволюції, а саме ті, що грунтується на засобах:

- лінійного програмування або ЛП (Г. І. Карімов, Амрін Г., Річі Дж., Моді I., Дзюбан І. Ю., Листопад В.В);

-лінійного програмування із використанням транспортних матриць (Гетьман О.О., О.В. Іваницька, Н. В. Рощина, Р.С. Сербул);

- динамічного програмування (Соколовська 3.М., Яценко Н. В., Хортюк М. В., Бхондекар, Мол, П., \& Виг, Р.);

- теорії масового обслуговування (Ложковський А. Г., Штрік Дж., Тютюнник Ю.М.;

- теорії ігор (Льюс Р., Райфа Х., Олешко Т.І., Лобанов М.О.). 
Розглянемо сутність кожного 3 виділених підходів, їх особливості, доцільність застосування для ідентифікації стану спорідненості процесів виробничо-господарської діяльності та напрямів їх еволюції.

Підхід, що грунтується на засобах лінійного програмування або ЛП (Г. I. Карімов [145], Амрін Г., Річі Дж., Моді I. [138], Дзюбан I. Ю.[142], Листопад В.В.[146]) передбачає, що за процесами виробничо-господарської діяльності організацій формується система лінійних нерівностей, що визначають стан спорідненості та напрямки іï еволюції за безліччю рішень (це здійснюється за системою обмежень задач лінійного програмування). Закономірно, лінійна функція $\mathrm{f}(\mathrm{x}) \epsilon$ цільовою функцією, що придатна для ідентифікації розвитку спорідненості за цільовими формальними групами видавця/розробника кіберспортивної гри. При цьому підхід має ряд недоліків, що обмежують можливості його застосування для кіберспортивних організацій. Зокрема, відмічена відсутність усталеного підходу до систематизованої сукупності кроків з ідентифікації системогенезу та онтогенезу процесів виробничо-господарської діяльності. Для реалізації цих задач пропонуються до використання: графічного методу рішення, симплекс-методу, двоїстого симплекс-методу (Р-метод), методу Гоморі; параметричного програмування; дрібно-лінійного програмування [145, c. 5]. Крім того, за описом особливостей ідентифікації ситемогенезу функціональних систем організацій та онтогенезу їх розвитку за сукупністю методів ЛП (табл. 4.5.1), можна констатувати, що:

1) за будь-яким з цих кроків складно чітко ідентифікувати реальний зміст еволюції різновекторних процесів у середні споріднених кіберспортивних організацій, якщо змінюється лише одна змінна. Наприклад, якщо кіберспортивні організації, за результатами генерування потужностей реплікації та масштабування, подвоять продажі окремого кіберспортивного продукту, а все інше залишається незмінним, рівняння покаже подвоєння доходу;

2) неможливо ідентифікувати уподібнення та зміст еволюції різновекторних процесів у середні споріднених кіберспортивних організацій, якщо ряд таких процесів (або X відносно Y) будуть знаходяться у нелінійних залежностях. 
Наприклад, якщо подвоюється бюджет на оновлення технічних можливостей забезпечення контенту та ігрового процесу, це не означає, що еволюція виробничого процесу збільшить прибуток кіберспортивних організацій;

3) рівняння формуються грунтуючись з певних припущень, обмежень, що $є$ елементами ідентифікації природньої течії еволюції, щодо спорідненості процесів виробничо-господарської діяльності кіберспортивних організацій 3 моменту їх утворення до зникнення. Припущення та обмеження можуть бути невірними (наприклад, припускається, прискорення виробництва програмних кодів потроїть продажі кіберспортивного продукту (користуючись зі збільшення кількості кіберспортсменів на кіберспортивних подіях), але насправді воно насичує ринок.

4) рівняння щодо процесів виробничо-господарської діяльності мають занадто багато можливостей, щоб вписатися у формулу лінійного програмування (оскільки умови реалізації цих процесів можуть потребувати феноменології).

Недоліки підходу, що грунтується на засобах лінійного програмування, також виділяються у фундаментальних працях, присвячених дослідженню операцій, серед яких: Беллман Р.[139], Вентцель Е.С.[140].

\section{Таблиця 4.5.1}

Особливості ідентифікації ситемогенезу функціональних систем організацій та онтогенезу їх розвитку за сукупністю метолів ЛП*

\begin{tabular}{|c|c|c|}
\hline $\begin{array}{l}\text { Методи } \\
\text { рішення }\end{array}$ & $\begin{array}{l}\text { Особливості } \\
\text { методу ЛП }\end{array}$ & Специфіка застосування ЛП \\
\hline Графічний & 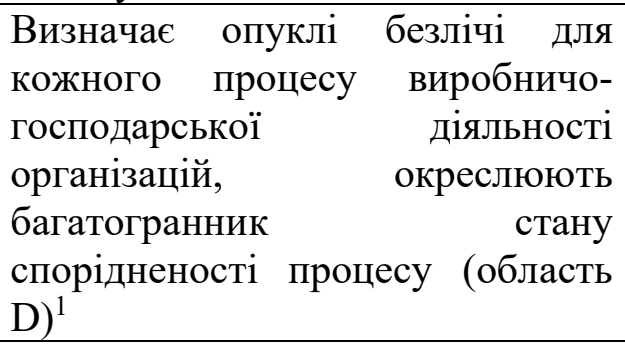 & $\begin{array}{l}\text { Побудова області } \mathrm{D} \text {; знаходження gradF i } \\
\text { його побудови; знаходження екстремуму } \\
\text { функції по першій і останній точках області } \\
\text { D }\end{array}$ \\
\hline Симплекс & \multirow[t]{2}{*}{$\begin{array}{l}\text { Визначає специфіку послідовної } \\
\text { еволюції кожного процесу } \\
\text { виробничо-господарської } \\
\text { діяльності } 2\end{array}$} & $\begin{array}{l}\text { Визначає за конкретне число кроків } \\
\text { оптимістичний } \\
\text { спорідненості по ЛП і зант відповідними } \\
\text { окремим процесом. }\end{array}$ \\
\hline Гоморі & & 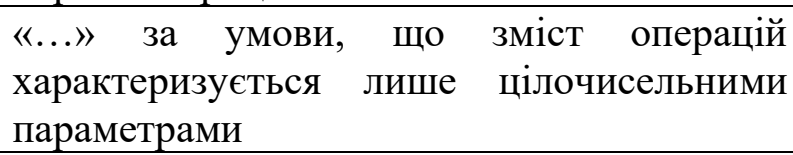 \\
\hline
\end{tabular}




\begin{tabular}{|c|c|c|}
\hline $\begin{array}{l}\text { Параметричн } \\
\text { ого } \\
\text { програмуванн } \\
\text { я }\end{array}$ & $\begin{array}{l}\text { Визначає специфіку послідовної } \\
\text { еволюції кожного процесу } \\
\text { виробничо-господарської } \\
\text { діяльності з урахуванням системи } \\
\text { обмежень що залежать від певних } \\
\text { параметрів } 2\end{array}$ & $\begin{array}{l}\text { Дозволяє за конкретне число кроків } \\
\text { отримати різні оптимальні варіанти } \\
\text { еволюції спорідненості по ЛП за окремим } \\
\text { процесом, за умови, що результат еволюції } \\
\text { (цільова функція) має обмеження, що } \\
\text { залежать від одного або декількох } \\
\text { параметрів t. }\end{array}$ \\
\hline $\begin{array}{l}\text { Двоїстий } \\
\text { симплекс (Р- } \\
\text { метод) }\end{array}$ & $\begin{array}{l}\text { Визначає специфіку послідовної } \\
\text { еволюції кожного процесу } \\
\text { виробничо-господарської } \\
\text { діяльності } \quad \text { із можливим } \\
\text { дослідженням варіаторіки }\end{array}$ & 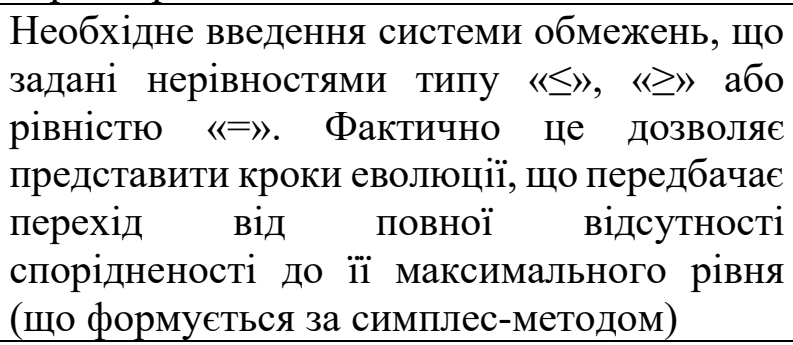 \\
\hline $\begin{array}{l}\text { Дрібно- } \\
\text { лінійне } \\
\text { програмуванн } \\
\text { я }\end{array}$ & $\begin{array}{l}\text { Визначає специфіку послідовної } \\
\text { еволюції процесу виробничо- } \\
\text { господарської діяльності, якщо } \\
\text { потрібно оптимізувати цей } \\
\text { процес } 3 \text { урахуванням системи } \\
\text { обмежень що залежать від певних } \\
\text { параметрів }\end{array}$ & $\begin{array}{l}\text { Необхідне отримання цільової функції } \\
\text { природної еволюції за змінними, що є } \\
\text { відношеннями двох лінійних функцій. Така } \\
\text { особливість значно ускладнює процес } \\
\text { ідентифікації онтогенезу та потребує } \\
\text { застосування спеціалізованих методів } \\
\text { обробки даних Знаменник цільової функції } \\
\text { еволюції має бути виключно позитивним, } \\
\text { та не може дорівнювати нулю в області D }\end{array}$ \\
\hline
\end{tabular}

Примітка

* Результат застосування методу ЛП: 1 математичний опис спорідненості процесів у поточний момент; 2 побудова тренду еволюції спорідненості організацій; 3 побудова трендів еволюції спорідненості організацій, що трансформуються коштом вільних членів bi, що можуть приймати будь-які значення; 4 побудова трендів еволюції спорідненості організацій, що будуються за змінними дрібно-лінійного виду. При цьому системи обмежень для функцій залишаються лінійними

Джерело: сформовано на основі [138-141]

\section{Підхід, що грунтусться на засобах лінійного програмування із} застосуванням транспортних матриць (Гетьман О.О. [141], О. В. Іваницька, Н. В. Рощина, Р. С. Сербул, [144]) специфічний тим, що орієнтується на процеси виробничо-господарських операцій організацій мають формуватися транспорті матриці (за цією логікою для формальних груп кіберспортивних організацій ці матриці мають узагальнювати деталізовані змінні, щодо вартості цифрових кіберспортивних продуктів, можливостей із перетворення цих продуктів на кіберспортивні послуги (що потрібно розподілити за ігровими спільнотами) та командними склади, команди, клуби, ліги, за якими їх необхідно розподілити). Підхід має ряд недоліків, що обмежують можливості його застосування для кіберспортивних організацій. Зокрема, відмічена відсутність усталеного підходу до систематизованої сукупності кроків з ідентифікації еволюції спорідненості 
кіберспортивних організацій за наявними процесами, оскільки, окрім класичної транспортної матриці (або матриці Хітчкок-Купманса), до використання пропонуються методи: диференціальних рент або метод призначення). Крім того, наявна відсутність усталеного підходу до ідентифікації уподібнення процесів виробничо-господарської діяльності, відтак у середні цільових формальних груп видавця/розробника кіберспортивної гри до використання пропонуються методи мінімального елемента, північно-західного кута, апроксимації Фогеля, подвійної переваги (особливості застосування та переваги яких не вказуються).

Також за описом особливостей застосування наявних методів програмування із застосуванням транспортних матриць (табл. 4.5.2) можна зробити висновок, що базовою умовою застосування підходу є контрольованість еволюції спорідненості кіберспортивних організацій, що можливе лише для тих видавців/розробників кіберспортивної гри, що мають закриті бізнес-екосистеми, які не набули значного поширення.

Таблиця 4.5.2

Особливості ідентифікації ситемогенезу функціональних систем організацій та онтогенезу їх розвитку за сукупністю метолів ЛП із застосуванням транспортних матриць

\begin{tabular}{|c|c|c|}
\hline & $\begin{array}{l}\text { Особливості алгоритму дій методу ЛП із } \\
\text { застосуванням транспортних матриць }\end{array}$ & $\begin{array}{l}\text { Специфіка, застосування ЛП із } \\
\text { транспортними матрицями }\end{array}$ \\
\hline $\begin{array}{l}\text { класична } \\
\text { транспортна } \\
\text { матриця } \\
\text { (або } \\
\text { матриця } \\
\text { Хітчкок- } \\
\text { Купманса) }\end{array}$ & $\begin{array}{l}\text { Формування опорної транспортної матриці за } \\
\text { змінними, що обмежені на пропускну } \\
\text { здатність** (наприклад. щодо перетворення } \\
\text { цифрового продукту на кіберспортивні } \\
\text { послуги). Ця матриця визначає поточний стан } \\
\text { виробничо-господарських процесів, щодо яких } \\
\text { досліджується можливість оптимістичного } \\
\text { варіанту еволюції }\end{array}$ & $\begin{array}{lr}\text { Ідентифікація } & \text { еволюції } \\
\text { спорідненості } & \\
\text { кіберспортивних } & \text { організацій } \\
\text { за кожним окремим продуктом } \\
\text { чи послугою, за умови, що є } \\
\text { обмеження на розвиток } \\
\text { формальних } \\
\text { кіберспортивних організацій }\end{array}$ \\
\hline $\begin{array}{l}\text { диференціс } \\
\text { ьних рент }\end{array}$ & $\begin{array}{l}\text { Формування опорної транспортної матриці за } \\
\text { змінними, що обмежені за розподілом } \\
\text { інформаційних продуктів та послуг**. У } \\
\text { стовпцях вказується мінімальний тариф на } \\
\text { доведення нематеріального продукту до } \\
\text { споживача / або максимальний прибуток від } \\
\text { цього. Знайдені числа позначають колом, а } \\
\text { клітини, в яких стоять ці числа, заповнюють. У } \\
\text { них записують максимально можливі числа. }\end{array}$ & 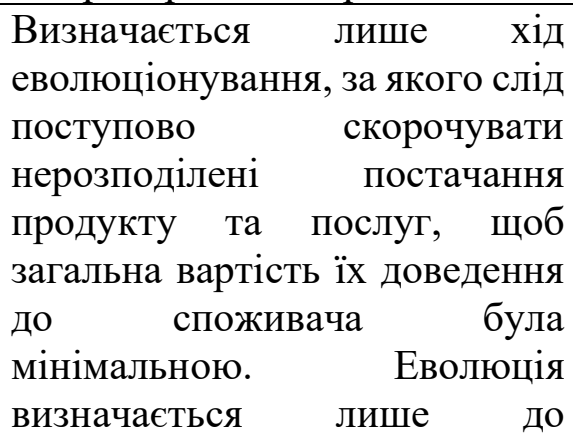 \\
\hline
\end{tabular}




\begin{tabular}{|c|c|c|}
\hline & $\begin{array}{l}\text { Формується розподіл, що не задовольняє } \\
\text { обмеженням вихідної транспортної задачі. В } \\
\text { результаті подальших кроків ідентифікується } \\
\text { хід еволюціонування. Для визначення ходу } \\
\text { еволюціонування мають бути визначені } \\
\text { надлишкові/недостатні рядки* }\end{array}$ & $\begin{array}{l}\text { моменту, } \quad \text { нерозподілений } \\
\text { залишок ресурсів стане рівним } \\
\text { нулю }\end{array}$ \\
\hline призначення & $\begin{array}{l}\text { Формування опорної транспортної матриці за } \\
\text { змінними та за розподілом виробничих і } \\
\text { господарських робіт у межах формальних } \\
\text { груп**. Вважається, що є деяке число робіт і } \\
\text { деяке число виконавців. Потрібно розподілити } \\
\text { роботи так, щоб виконати їх } 3 \text { мінімальними } \\
\text { витратами для видавця/розробника конкретної } \\
\text { кіберспортивної гри.. }\end{array}$ & $\begin{array}{l}\text { Будь-який виконавець } \\
\text { бути поже } \\
\text { виконання бризначений } \quad \text { нудь-якої } \\
\text { тільки одне } \\
\text { неоднаковими роботи } 3 \\
\text { не митратами. Це } \\
\text { виконавець може виконувати } \\
\text { кілька або всі роботи. } \\
\end{array}$ \\
\hline
\end{tabular}

Примітка

* рядки, що відповідають сервісам та продуктам видавця/розробника кіберспортивної гри, ресурси яких повністю розподілені, а потреби пунктів призначення, пов'язаних з даними споживачами та запланованими постачаннями, не задоволені або недостатні. Рядки, ресурси яких вичерпані не повністю, є надмірними.

**здійснюється методами мінімального елемента, північно-західного кута; апроксимації Фогеля; подвійної переваги.

Джерело: сформовано на основі [141, с. 7]

Підхід фактично орієнтує на ідентифікацію уподібнення процесів виробничо-господарської діяльності та їх еволюцію за кожним окремим цифровим продуктом видавців/розробників, сервісною чи іншою послугою. За значної кількості сервісів та послуг формується громіздка система матриць, що має велику кількість змінних та продукує громіздкі розрахунки.

Підхід, що грунтусться на засобах теорії масового обслуговування (Ложковський А. Г. [147], Штрік Дж. [156], Тютюнник Ю.М. [150]) передбачає кількісну оцінку процесів обслуговування вимог споживачів продукції, товарів, послуг у системі масового обслуговування (CMO), коштом ймовірностей та математичних методів масового обслуговування. При цьому СМО - це система, яка виконує обслуговування вимог споживачів, що надходять до неї [156]. Відповідно до змісту теорії, кількісну оцінку таких процесів, у межах цільових формальних груп видавця/розробника кіберспортивної гри, необхідно реалізувати за систематизованими кроками, які придатні для кількісної оцінки процесів багатоканальних систем, кількість пристроїв обслуговування $\mathrm{n}$ (кількість робочих, сервісів та ін.) у яких більше одного. За описом особливостей застосування методу кількісної оцінки багатоканальних систем, наявних у 
підході, що грунтується на теорії масового обслуговування (табл. 4.5.3) можна зробити висновок, що підхід має ряд недоліків, що обмежують можливості його застосування для кіберспортивних організацій. Зокрема, кількісна оцінка ідентифікує лише стан процесів обслуговування вимог ігрових спільнот, командних складів, команд, клубів, ліг. Мова йде про стан процесів обслуговуванням вимог споживачів, щодо завантаження ігор на жорсткий диск ігрового комп’ютера, черга на отримання цифрового ключа (при поширенні ігор за спеціальною схемою). У той час як їх зміст та зміст процесів виробничогосподарської діяльності організацій цільових формальних груп видавця/розробника кіберспортивної гри ширший ніж просте обслуговування вимог ігрових спільнот, командних складів, команд, клубів, ліг. Методи рішення не враховують багатоступеневості структуру процесу, а лише ідентифікують їі можливу конфігурацію.

Таблиця 4.5.3

Особливості ідентифікації ситемогенезу функціональних систем організацій та онтогенезу їх розвитку за сукупністю методів теорії масового обслуговування

\begin{tabular}{|c|c|c|c|}
\hline $\begin{array}{l}\text { Методи } \\
\text { рішення }\end{array}$ & $\begin{array}{ll}\text { Особливості } & \\
\text { алгоритму } & \text { дій } \\
\text { методу } & \text { теорії } \\
\text { масового } & \\
\text { обслуговування } & \end{array}$ & Варіації застосування методу & $\begin{array}{l}\text { Специфіка, } \\
\text { застосування методу. } \\
\text { теорії масового } \\
\text { обслуговування }\end{array}$ \\
\hline \multirow[t]{2}{*}{$\begin{array}{l}\text { Кількісна } \\
\text { оцінка } \\
\text { багатоканал } \\
\text { ьних систем }\end{array}$} & \multirow{2}{*}{ 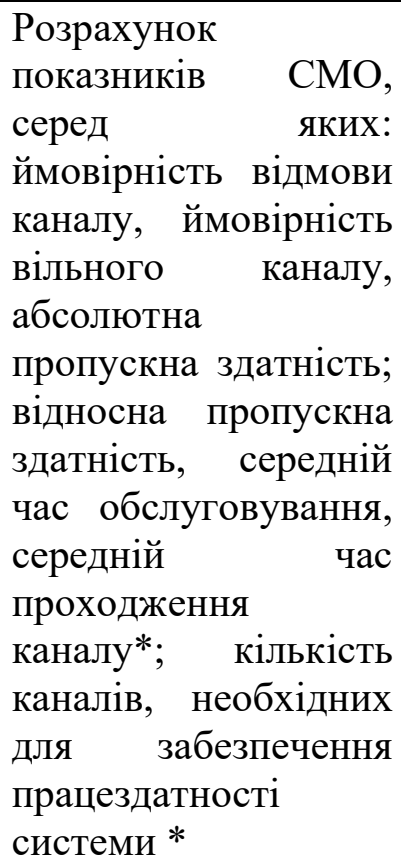 } & $\begin{array}{l}\text { Багатоканальна СМО } \\
\text { відмовами у обслуговуванні } \\
\text { вимог споживачів. Ідентифікує } \\
\text { ситуації за яких запит отримує } \\
\text { відмову (зазвичай це ситуація, } \\
\text { за якої всі канали } \\
\text { обслуговування зайняті) }\end{array}$ & \multirow{2}{*}{$\begin{array}{l}\text { Метод, за будь-якою з } \\
\text { варіацій застосування, } \\
\text { ідентифікує лише: } \\
\text { - стан процесів } \\
\text { обслуговуванням } \\
\text { вимог споживачів, } \\
\text { щодо завантаження } \\
\text { ігор, поширення ігор } \\
\text { за спеціальною } \\
\text { схемою,; } \\
\text { - конфігурацію такої } \\
\text { системи. } \\
\text { Метод не визначає } \\
\text { еволюцію даного } \\
\text { процесу. }\end{array}$} \\
\hline & & $\begin{array}{l}\text { Багатоканальна СМО } \\
\text { обмеженою довжиною черги. } \\
\text { Ідентифікує ситуації за яких } \\
\text { запит знаходиться у режимі } \\
\text { очікування поки не звільниться } \\
\text { канал обслуговування (разом } 3 \\
\text { тим у черзі може передувати } 1 \\
\text { запит). }\end{array}$ & \\
\hline
\end{tabular}




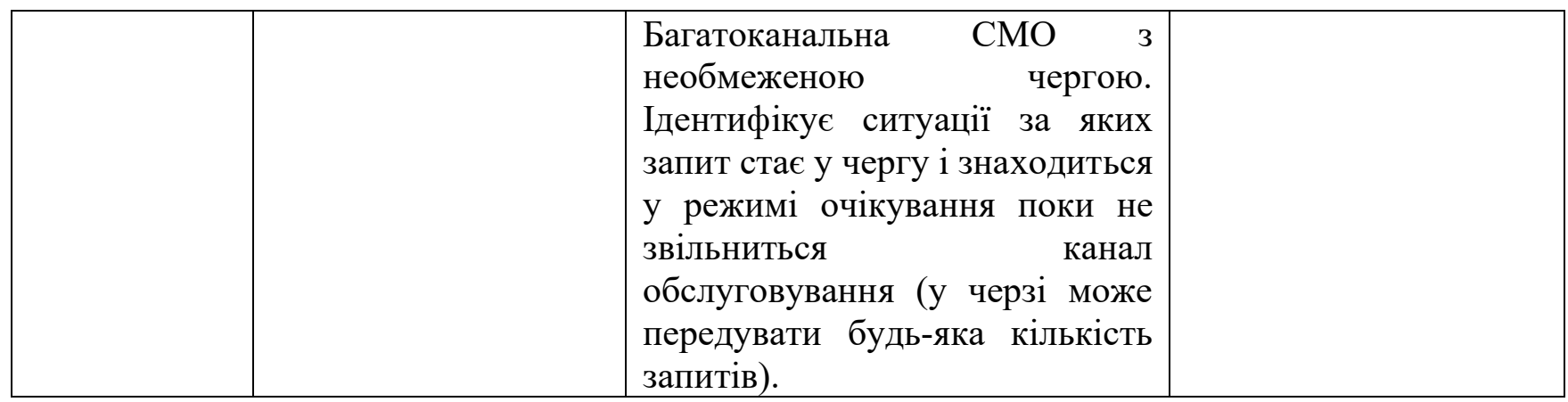

Примітка

*вхідними даними $є$ інтенсивність потоку замовлень, інтенсивність потоку обслуговування, кількість каналів обслуговування.

Джерело: сформовано на основі $[147$, с. 13, с. 19]

Підхід, що грунтується на засобах теорії ігор (Льюс Р., Райфа Х. [148], Олешко Т.І., Лобанов М.О. [149]) передбачає, що всі процеси оцінюються як такі, що реалізуються в умовах невизначеності або конфлікту сторін цільових формальних груп видавця/розробника кіберспортивної гри. У цьому випадку дійсно видавець/розробник кіберспортивної гри та його ігрові спільноти (включаючи людей, які не обов'язково $є$ покупцями зараз, але точно стануть ними в майбутньому), командних складів, команд, клубів, ліг мають різні інтереси. Так, видавець/розробник прагне до максимального розширення організацій, що об’єднанні почуттям спільності, щодо їх діяльності (оскільки це гарантує сталість доходів від цифрової гри). Учасники ігрових спільнот, командних складів, команд, клубів, ліг діють кожен у своїх фінансових інтересах, за виключенням випадків їх переходу на франшизну систему, коли ліги ділять доходи з командами-учасниками. Специфічними, щодо підходу є те, що за сукупністю кроків підхід націлений на вивчення оптимальної еволюції процесів виробничо-господарської діяльності, ідентифікуючи їх як множинні ситуації ігрового характеру. До них відносяться:

1) ситуації, пов'язані з вибором найвигідніших виробничих рішень (видавця / розробника кіберспортивної гри, кіберспортивних арен видавця/ розробника, клубів і тренувальних центів);

2) ситуації, пов'язані з вибором найвигідніших збутових рішень видавця/ розробника, кіберспортивних арен; 
3) ситуації, пов’язані з вибором найвигідніших рішень, щодо розподілу ресурсів.

Специфічним $є$ те, що ідентифікуючи ситуації ігрового характеру математично, представники підходу прагнуть формалізувати їх стан та онтогенез. Вони представляються у множинній грі двох, трьох або більшої кількості гравців, кожен з яких переслідує ціль з максимізації вигоди, коштом іншого. У межах підходу пропонуються різні методи та варіації рішення гри гравців (щодо застосування яких немає усталеного підходу). Особливості ідентифікації ситуації ігрового характеру для виробничих та господарських рішень за сукупністю методів теорії ігор систематизовані у табл. 4.5.4.

Таблиця 4.5.4

Особливості ідентифікації ситуації ігрового характеру для виробничих та господарських рішень за сукупністю методів теорії ігор

\begin{tabular}{|c|c|c|c|}
\hline $\begin{array}{l}\text { Методи } \\
\text { рішення }\end{array}$ & варіації рішення гри гравців & $\begin{array}{l}\text { Особливості } \\
\text { алгоритму дій методу } \\
\text { теорії ігор }\end{array}$ & $\begin{array}{l}\text { Специфіка, } \\
\text { застосування } \\
\text { теорії ігор* }\end{array}$ \\
\hline \multirow{4}{*}{$\begin{array}{l}\text { ідентифікаці } \\
\text { я } \\
\text { оптимальної } \\
\text { ігрової } \\
\text { ситуації }\end{array}$} & $\begin{array}{l}\text { Мінімакс (пошук чистої стратегії } \\
\text { гравців або точок рівноваги) }\end{array}$ & \multirow{4}{*}{$\begin{array}{l}\text { Задаються платіжні } \\
\text { матриці. у межах } \\
\text { кроків здійснюється } \\
\text { пошук чистих або } \\
\text { змішаних стратегій } \\
\text { гравців i, ціни гри. }\end{array}$} & \multirow{7}{*}{$\begin{array}{l}\text { Еволюція } \\
\text { спрямована на } \\
\text { ідентифікацію } \\
\text { конфліктних } \\
\text { ситуацій між } \\
\text { учасниками гри. } \\
\text { стан виробничих } \\
\text { та господарських } \\
\text { процесів чітко не } \\
\text { ідентифікується; } \\
\text { ідентифікації } \\
\text { еволюції можливо } \\
\text { тільки якщо по } \\
\text { кожному з гравців } \\
\text { відомі всі його } \\
\text { можливі дії, щодо } \\
\text { виробничо- } \\
\text { господарської } \\
\text { діяльності }\end{array}$} \\
\hline & $\begin{array}{lcc}\text { Симплекс } & \text { (пошук } & \text { змішаних } \\
\text { стратегій } & \text { методами } & \text { лінійного } \\
\text { програмування) } & \end{array}$ & & \\
\hline & $\begin{array}{l}\text { Графічний (пошук змішаних } \\
\text { стратегій до точки рівноваги) }\end{array}$ & & \\
\hline & $\begin{array}{l}\text { Iтераційний } \frac{\text { Брауна-Робінсона }}{\text { (пошук наближеного значення ціни }} \\
\text { гри, причому істинне значення } \\
\text { можна отримати } 3 \text { будь-яким } \\
\text { ступенем точності). }\end{array}$ & & \\
\hline $\begin{array}{l}\text { біматрична } \\
\text { гра }\end{array}$ & $\begin{array}{l}\text { Варіації рішення гри гравців не } \\
\text { передбачені }\end{array}$ & $\begin{array}{l}\text { Задають 2-і } \\
\text { однакового } \\
\text { возмиціру } \\
\text { виграшів } 1 \text {-ого і 2-ого } \\
\text { гравців. }\end{array}$ & \\
\hline \multirow[t]{2}{*}{$\begin{array}{ll}\text { гра } & 3 \\
\text { природою }\end{array}$} & $\begin{array}{l}\text { Максимакса, Байєса, Лапласа } \\
\text { (обираються шляхи еволюції, що } \\
\text { забезпечують } \\
\text { виграш) } \\
\text { максимальний }\end{array}$ & \multirow{2}{*}{$\begin{array}{l}\text { Здентифікуються } \\
\text { напрямки еволюції за } \\
\text { критеріями } \\
\text { Максимакс, Байєса, } \\
\text { Лапласа, Вальда, } \\
\text { Севіджа, Гурвіца. }\end{array}$} & \\
\hline & $\begin{array}{l}\text { Вальда } \quad \text { (обираються } \quad \text { шляхи } \\
\text { еволюції, } \\
\begin{array}{l}\text { максимальний виграш за найгірших } \\
\text { ситуацій) }\end{array}\end{array}$ & & \\
\hline
\end{tabular}




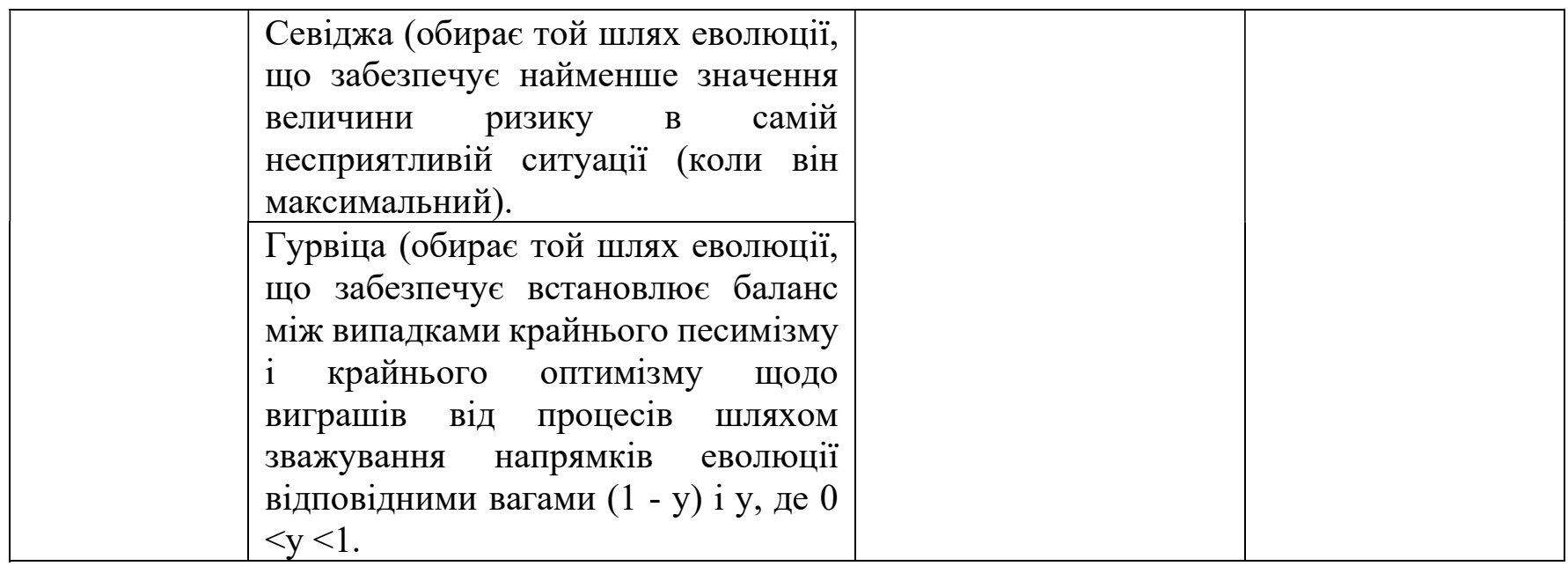

Примітка

* значення у від 0 до 1 може визначатися за схильністю гравців, що приймають рішення, до песимізму або оптимізму. За відсутності яскраво вираженої схильності представляється найбільш розумним значення $\mathrm{y}=0,5$.

Джерело: сформовано на основі [147, с. 13, с. 19]

За розглядом їх особливостей можна зробити висновок, що підхід має ряд недоліків, що обмежують можливості його застосування для кіберспортивних організацій, зокрема: 1) еволюція спрямована на ідентифікацію конфліктних ситуацій між учасниками гри., а сам стан виробничих та господарських процесів чітко не ідентифікується; 2) можливе застосування тільки якщо по кожному 3 гравців відомі всі його можливі дії, щодо виробничо-господарської діяльності (за виключенням того, якими з них він скористається).

Підхід, що грунтується на засобах динамічного програмування (Соколовська 3.М., Яценко Н. В., Хортюк М. В. [154]) передбачає, що за всіма процесами виробничо-господарської діяльності організацій здійснюється відтворення їх первинного стану, ідентифікація можливих напрямків еволюції спорідненості (шляхом пошуку розв'язків, отриманих розбиттям змін на послідовні проміжки часу). Це виражається у відзначенні послідовності змін множинних значень функцій V1, V2, ..., Vn, з аргументом у, котрі позначають стан всіх або окремого процесу в моменти часу і від 1 до n. На відміну від інших підходів, у межах окресленого наявна чітка структурованість та уніфікованість кроків. Основні методи ДП, на яких грунтується підхід виділені у табл. 4.5.5. 
Особливості ідентифікації ситемогенезу функціональних систем організацій та онтогенезу їх розвитку за сукупністю методів ДП

\begin{tabular}{|c|c|c|}
\hline & ті алгоритму дій методу ДП & $\begin{array}{l}\text { Іфіка, } \\
\text { ування ДП* }\end{array}$ \\
\hline $\begin{array}{l}\text { Ідентифікаці } \\
\ddot{1} \quad \text { стану } \\
\text { розподілу } \\
\text { ресурсів }\end{array}$ & $\begin{array}{l}\text { Формується рівняння стану розподілу ресурсів } \\
\left(x_{k}+y_{k}=a_{k}\right) \text {, яке щодо сфери кіберспорту } \\
\text { відрізняються такими базовими параметрами* як: } \\
\text { кількість ресурсів, що виділяються для відтворення } \\
\text { кожного виду нематеріальних продуктів та } \\
\text { потужностей сервісів на кожному кроці. Еволюцію } \\
\text { процесу розподілу ресурсів визначаємо шляхом } \\
\text { рекурсії* та розбиваємо на етапи по роках (нумеруючи } \\
\text { починаючи від першого), що спрямовуються дією } \\
\text { змінної управління. }\end{array}$ & 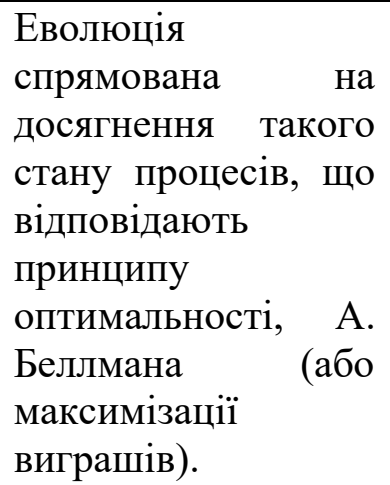 \\
\hline $\begin{array}{l}\text { Ідентифікаці } \\
\text { ï } \quad \text { стану } \\
\text { постачання }\end{array}$ & $\begin{array}{l}\text { Формується рівняння стану процесів постачання }\left(y_{t-1}=\right. \\
\left.y_{t}-x_{t}+d_{t}, t=1, \ldots, n\right) \text {, яке щодо сфери кіберспорту } \\
\text { відрізняються такими базовими параметрами** як: } \\
\text { число продуктів та послуг, виготовлених в t-му місяці } \\
\text { (етапі); рівень здатностей до реплікації та } \\
\text { масштабування на кінець t-го місяця; попит на } \\
\text { продукти та послуги в t-му місяці; витрати на } \\
\text { масштабування та реплікацію продукції та послуг в t- } \\
\text { му місяці. Еволюцію процесу стану постачання } \\
\text { розбиваємо визначаємо шляхом рекурсії* та на етапи, } \\
\text { що спрямовуються дією змінної управління. }\end{array}$ & $\begin{array}{l}\text { Змінна управління } \\
\text { обирається так, щоб } \\
\text { вона приводила до } \\
\text { виграшу, як на } \\
\text { даному етапі, так і } \\
\text { на всіх наступних } \\
\text { до кінця операції; } \\
\text { - за рівнянням стану } \\
\text { виробництва } \\
\text { найбільш бажаним є } \\
\text { вид рівняння } 3\end{array}$ \\
\hline $\begin{array}{l}\text { Ідентифік } \\
\ddot{1} \quad \text { ст } \\
\text { виробниц }\end{array}$ & 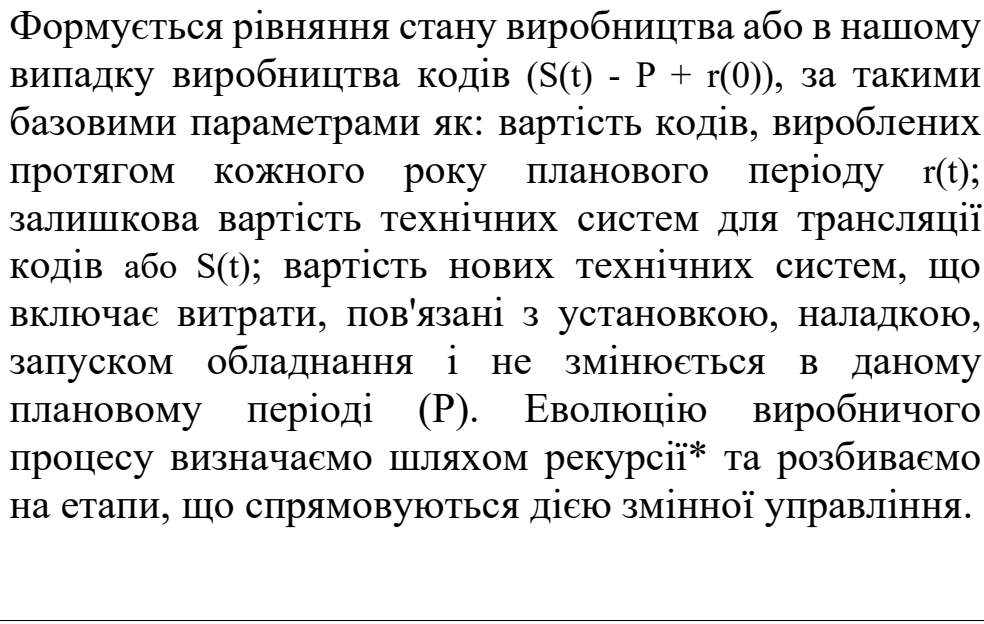 & $\begin{array}{l}\text { параметрами } \\
\text { збереження } \\
\text { виробничої системи } \\
\mathrm{Fk} \mathrm{(t)} \mathrm{для} \mathrm{k}= \\
5,4,3,2,1 \text {. } \\
\text { Спрощення пошуку } \\
\text { розв'язку складної } \\
\text { задачі, розбиттям іiі } \\
\text { на простіші } \\
\text { підзадачі; } \\
\text { вибір числа та умов } \\
\text { еволюції стану } \\
\text { процесів }\end{array}$ \\
\hline
\end{tabular}

\section{Примітка}

* $x_{k}, y_{k}$ кількість коштів, що виділяються на відтворення кожного виробі, продукту чи послуги; $a_{k}$ - дохід, який отримується від виробів, продуктів, послуг на k-му i всіх наступних.

** у класичному варіанті параметри є наступними: (xt) число виробів, виготовлених в $\mathrm{t}-$ му місяці (етапі); (yt ) рівень запасів на кінець t-го місяця; (dt) попит на виріб в t-му місяці; (ft $(\mathrm{xt}, \mathrm{yt}))$ - витрати на виробництво і зберігання виробів в t-му місяці.

** у класичному варіанті параметри є наступними: річний дохід $\mathrm{r}(\mathrm{t})$ і залишкова вартість $\mathrm{S}(\mathrm{t})$; вартість нової виробничої системи (Р). При обрахунку параметрів враховуються витрати на ремонт і подальшу експлуатацію виробничої системи; кількість одиниць обладнання, що формують виробничу систему; P (t) - щорічні витрати, пов'язані із заміною одиниць обладнання, що формують виробничу систему.

Джерело: сформовано на основі [154] 
Зокрема, за описом особливостей ДП, констатовано, що для ідентифікації стану процесів та їх еволюції пропонуються систематизовані кроки, орієнтовані на часткове їх визначення через себе або через використання раніше визначених станів:

1) ідентифікації стану розподілу ресурсів. Щодо цільових формальних груп видавця/розробника кіберспортивної гри важливий стан та еволюція ресурсів, що можуть бути використані для відтворення нематеріальних продуктів та потужностей сервісів, необхідних для їх існування і розвитку. Це ресурси ігрового аскета, інфраструктурні, обчислювальні (як значення кількості операцій з числа з плавучою комою в секунду);

2) ідентифікації стану постачання за цільовими формальними групами видавця/розробника кіберспортивної гри (зокрема, щодо доставляння власницького контенту, поширення ігор за стандартною схемою та за передплатою через спеціальний клієнт; щодо завантаження ігор);

3) ідентифікації стану виробництва. У цільових формальних групах важливим є створення технічно розвинених клубів і тренувальних центів, для команд, які представлятимуть свій регіон, і за які будуть вболівати мешканці цих регіонів. Виробництво відрізняються нематеріальним характером, орієнтованим на програмні коди, а ідентифікація їх стану та еволюції має зводитись до визначення можливостей, щодо створення кодів у багатофункціональних кіберспортивних майданчиках (аренах) та їх глобальних мережах, представлених одноформатними спеціалізованими клубами, базами з домашніми аренами для кіберспортсменів, навчально-тренувальними базами.

Відповідно до аналізу оптимальним, 3 точки зору унікалізування математичної моделі, є підхід до ідентифікації стану процесів виробничогосподарської діяльності кіберспортивних організацій та еволюції їх розвитку, що грунтується на методах динамічного програмування. Перевагою $є$ те, що унікалізування моделі реалізується паралельно із: 
- спрощенням пошуку спорідненості процесів, що вона відбиває, шляхом розбиття система математичних співвідношень на простіші підзадачі методом рекурсії;

- можливостями вибору числа та умов проведення дослідів, щодо еволюції стану процесів виробничо-господарської діяльності кіберспортивних організацій всередині цільових формальних груп видавця/розробника кіберспортивної гри. 